\title{
НОВЫЕ ДАННЫЕ О ЛИТОЛОГИЧЕСКОМ РАЗРЕЗЕ МАССИВА ЛЕДЯНОЙ ГОРЫ
}

\author{
А.В. Красиков, Д.Е. Трапезников \\ Горный институт УрО РАН, г. Пермь
}

\begin{abstract}
Аннотация: В статье приводится описание литологии скважины № 4444, пробуренной в массиве Ледяной горы. Дано детальное описание всех горных пород, которые были встречены в ходе бурения, а с помощью новых данных был дополнен существующий литолого-стратиграфический разрез. Было приведено описание образцов неволинской и елкинской пачек иренского горизонта кунгурского яруса пермской системы, которые в скважине № 4443 встречены не были. По результатам работ можно сделать предположение о том, что краевая часть массива была в меньшей степени подвержена разрушению, чем его центральная часть.
\end{abstract}

Ключевые слова: Кунгурская Ледяная пещера, карстовый массив, литогический разрез.

Введение. На территории ООПТ «Ледяная гора распространены породы кунгурского яруса приуральского отдела пермской системы. Ярус стратиграфически поделен на два горизонта: филипповский и иренский. Выше породы перекрыты отложениями неогеновой-четвертичной систем. Стратиграфия района представлена в работах многих исследователей [1-6]. Данные работы дают детальное описание литологического разреза города Кунгура и его окрестностей. Исследование литолого-петрографического состава массива Ледяная гора изучалось по данным бурения скважины № 4443. В ноябре 2012 года были построены разрез Ледяной горы и литолого-стратиграфическая колонка. [3]. Для получения новых данных о разрезе в октябреноябре 2018 года было проведено бурение второй скважины (№ 4444 в базе данных ГИ УрО РАН) в пределах горного отвода массива Ледяная гора, расположенной в 200 м на ЮЮВ от первой скважины (рис. 1). Авторами работы представлено дополненное описание литологического разреза по материалам, полученным в ходе бурения этой скважины.

Методика. Использование данных бурения позволило дополнить уже существующий литологический разрез Ледяной горы (рис. 2), и подтвердить положение о том, что массив представляет собой толщу переслаивающихся сульфатно-карбонатных пород. Кроме того, добавлено описание демидковской и елкинской пачек, которые в скважине 4443 не представлены, либо представлены частично (фрагмент ксенолита елкинской пачки). В предыдущих работах были описаны лишь немногочисленные выходы пород этих пачек, встреченных в пределах массива в обнажениях, либо бортах карстовых воронок.

Результаты. В разрезе скважины 4444 сверху вниз вскрыты отложения четвертичной коры выветривания, иренской (демидковская, елкинская, шалашнинская, неволинская и ледянопещерская пачки) и филипповской свиты кунгурского яруса приуральского отдела пермской системы (табл. 1).

Отложения неоген-четвертичной коры выветривания (интервал глубин 0-7,3 м) представлены дресвяно-щебнистым материалом глинистого доломита в глинистом матриксе светло-бежевого цвета. На интервале 1,2-2,0 м выделяется прослой бежевой глины с щебнем глинистого доломита). Обломки неравномернозернистые (от 0,5 до 10 см), неокатанные, угловатые, сильновыветрелые. В подошве коры залегает сероватокоричневый суглинок (интервал 3,8-4,8 м) и щебень доломита в глинистой «рубашке», разрушенной тюйской пачки (интервал 4,8-7,3 м).

Демидковская пачка (7,3-20,6 м) в верхней части представлена сильнотрещиноватым гипсом, ниже по разрезу серой гипсовой породой с сетчато-желваковой текстурой. Гипс мелкокристаллический слагает желваки линзовидно-овальной формы размером от 1 до 5 см. Границы желваков нечеткие, межжелваковое пространство заполнено доломитом пелитоморфным бежевого цвета. 


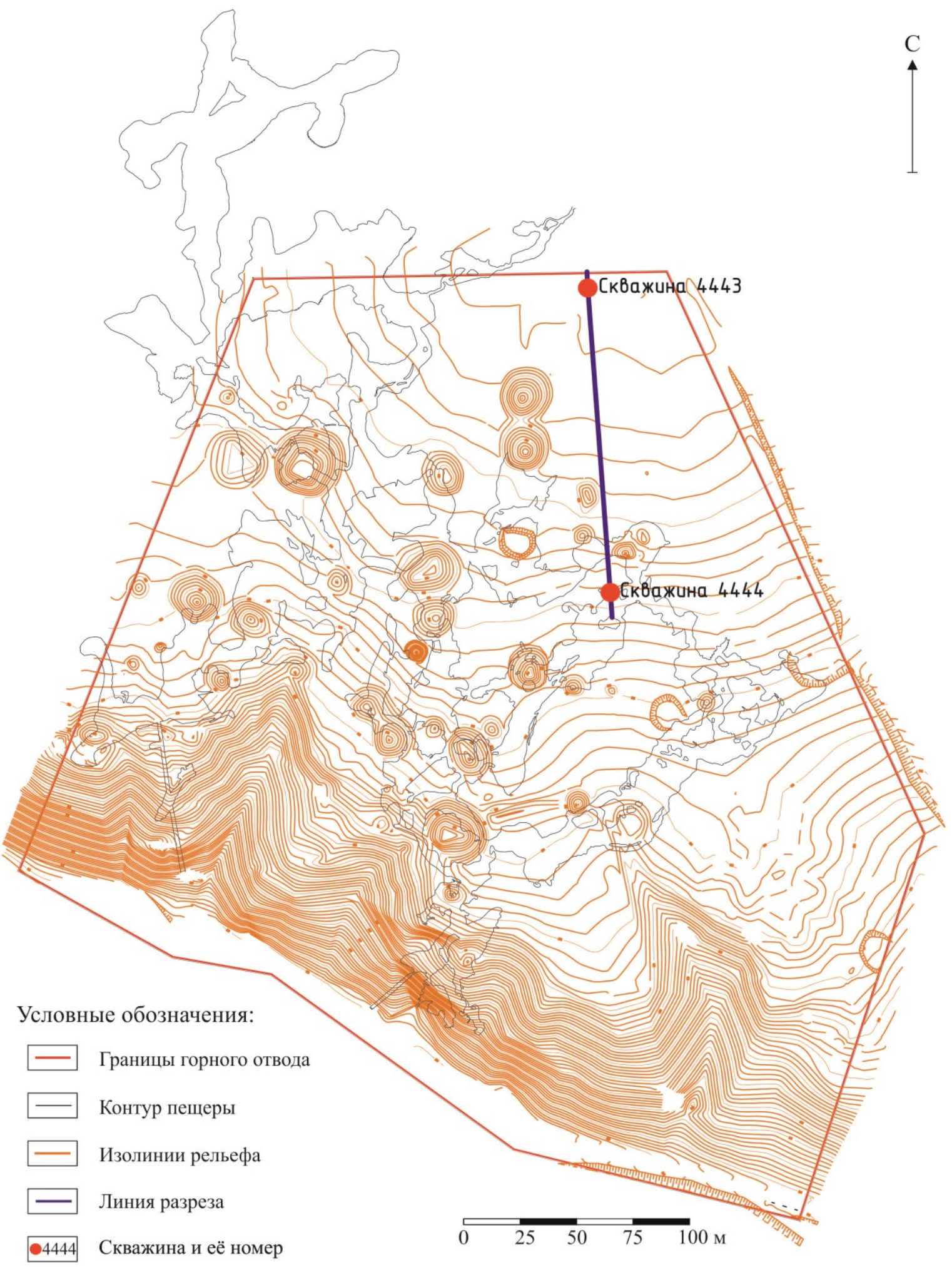

Рис. 1. Расположение скважин в пределах горного отвода ООО «Сталагмит-экскурс»

Елкинская пачка $(20,6-27,4$ м) представлена оолитовым доломитом бежевого цвета. Оойды размером от 0,5 до 1,5 мм, обычно округлой формы, редко встречаются овальные. Строение оойдов концентрически-зональное. Ядро оойдов либо пелитоморфное, либо полое, либо замещено гипсом или кальцитом. Слойки вокруг ядра сложены пелитоморфным доломитом. 


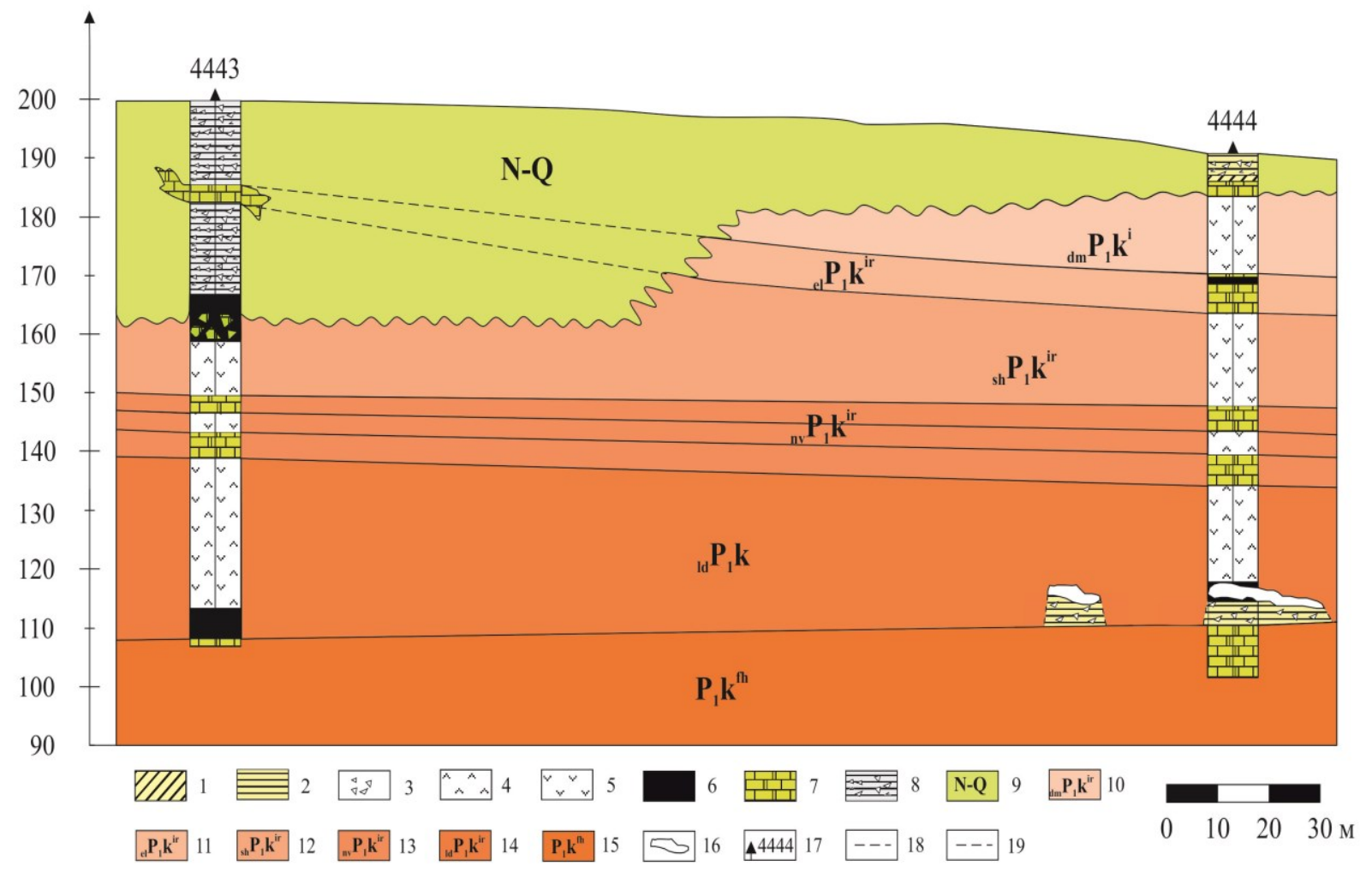

Рис. 2. Геологический разрез массива Ледяной горы.

Составлен на основе геологического разреза, выполненного Кадебской О.И., Калининой Т.А. [2]. Условные обозначения: 1 - суглинок; 2 - глина; 3 - дресвяно-щебнистый грунт; 4 - ангидрит; 5 - гипс; 6 - провалы инструмента/полости; 7 - доломит; 8 глина с щебнем доломита; 9 - неоген-четвертичные отложения; 10-14 - пачки (10 - демидковская;11 - елкинская; 12 - шалашнинская; 13 - неволинская;

14 - ледянопещерская);15 - филипповский горизонт; 16 - гроты Кунгурской Ледяной пещеры; 17 - скважина и её номер; 18 - линии предполагаемого залегания елкинской пачки

Таблица 1

\section{Сводная литолого-стратиграфическая колонка скважины № 4444}

\begin{tabular}{|c|c|c|c|c|c|c|c|c|c|c|c|c|}
\hline \multirow{2}{*}{ 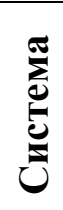 } & \multirow{2}{*}{ 5 } & \multirow{2}{*}{ 究 } & \multirow{2}{*}{ Ẽ } & \multirow{2}{*}{$\stackrel{\pi}{E}$} & \multirow{2}{*}{ } & \multirow{2}{*}{ نَّ } & \multirow[t]{2}{*}{$\begin{array}{c}\text { Описание } \\
\text { пород }\end{array}$} & \multicolumn{2}{|c|}{$\begin{array}{c}\text { Глубина } \\
\text { залегания, м }\end{array}$} & \multicolumn{2}{|c|}{$\begin{array}{c}\text { Абсолютные } \\
\text { отметки, м }\end{array}$} & \multirow{2}{*}{ 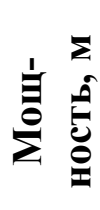 } \\
\hline & & & & & & & & OT & до & OT & до & \\
\hline \multirow{6}{*}{ 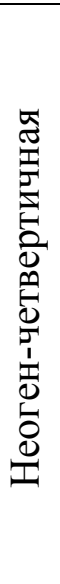 } & & & & & & 1 & $\begin{array}{l}\text { Почвенно- } \\
\text { расти- } \\
\text { тельный } \\
\text { слой }\end{array}$ & 0 & 0,3 & 191,2 & 190,09 & 0,3 \\
\hline & & & & & & 2 & Щебень & 0,3 & 1,2 & 190,9 & 190,0 & 1,2 \\
\hline & & & & & & 3 & Глина & 1,2 & 2 & 190,0 & 189,2 & 0,8 \\
\hline & & & & & & 4 & Щебень & 2 & 3,8 & 189,2 & 187,4 & 1,8 \\
\hline & & & & & & 5 & Суглинок & 3,8 & 4,8 & 187,4 & 186,4 & 1,0 \\
\hline & & & & & & 6 & $\begin{array}{c}\text { Щебень } \\
\text { доломита }\end{array}$ & 4,8 & 7,3 & 186,4 & 183,9 & 2,5 \\
\hline
\end{tabular}


Продолжение таблицы 1

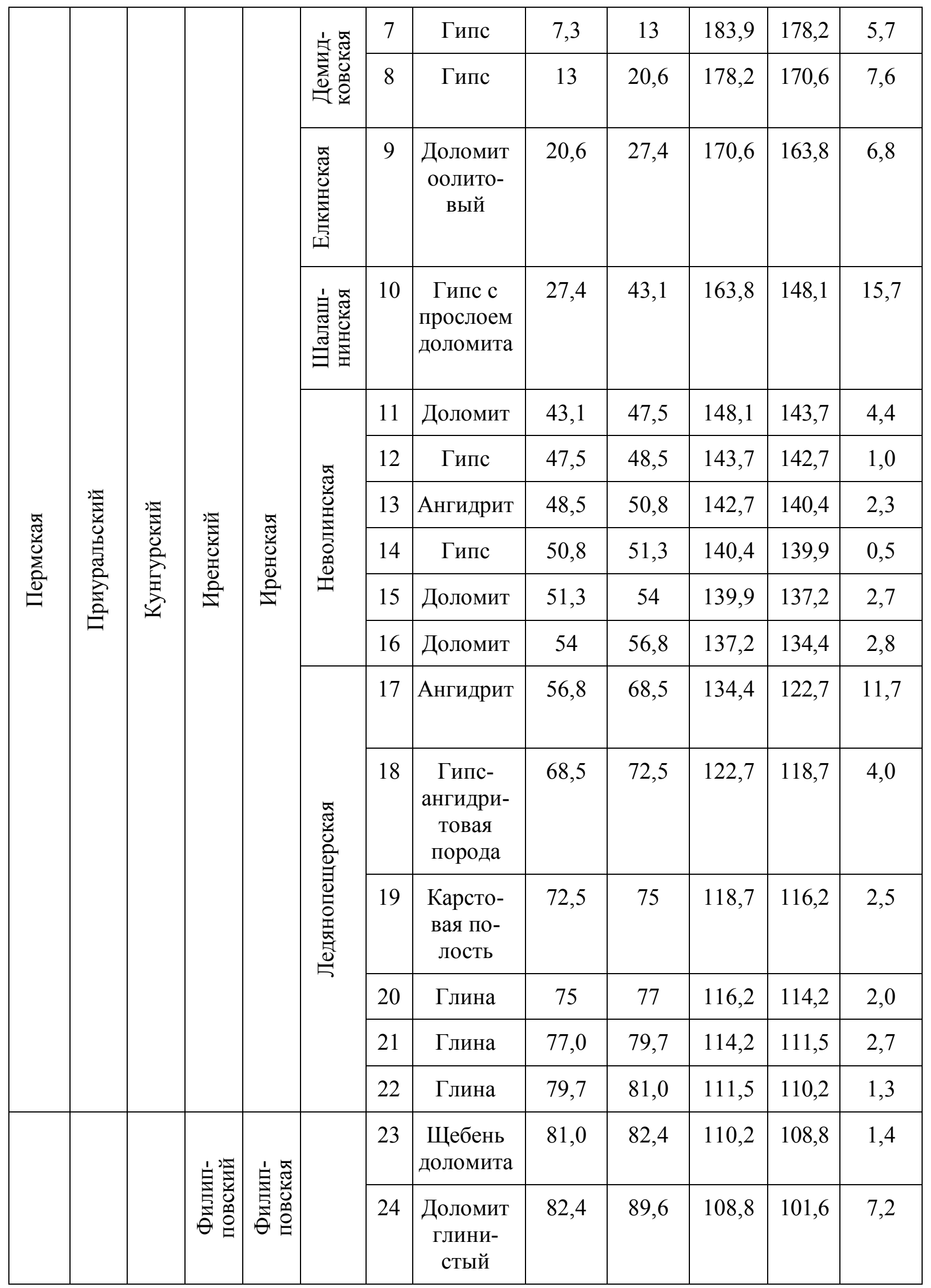


Шалашнинская пачка $(27,4-43,1$ м) в нижней и верхней части сложена гипсовой породой серого цвета с сетчато-желваковой текстурой. Гипс мелкокристаллический слагает желваки линзовидно-овальной формы. Размер желваков в верхней части от 1 до 3 см. Границы желваков нечеткие, межжелваковое пространство заполнено доломитом пелитоморфным бежевого цвета. В интервале 29,7-30.2 м встречен доломит бежевосерого цвета. Доломит преимущественно скрытокристаллический, бежевого цвета с плохо выраженной слоистостью.

Неволинская пачка $(43,1-56,8$ м) представлена доломитовой породой бежево-серого цвета с мощным прослоем ангидрит-гипсовой породы в центральной части.

Верхний доломитовый слой $(43,1-47,5$ м) в нижней части сложен доломитовой породой с тонкими (до 4 мм) прожилками гипса-селенита. На глубине 45,7 м встречена зона диагонального микросброса в виде нескольких открытых трещин, частично заполненных среднекристаллическим гипсом. Также, гипс присутствует в виде прожилков, вкрапленников и крупных пойкилокристаллов (до 3 см).

Верхняя часть слоя сложена доломит-гипсовой породой с пятнистой текстурой. Гипс представлен пойкилокристаллами, которые предположительно сформировались в полостях в доломите. Также в породе отмечаются субгоризонтальные прожилки волокнистого гипса толщиной до 3 мм.

Гипсовая порода $(47,5-48,5$ м) серого-цвета с мелкокристаллической структурой и с пятнистой или неясной сетчато-желваковой текстурой. Гипс в центре желваков белого цвета, а периферия серо-бежевого цвета.

Ангидрит-гипсовая порода $(48,5-50,8$ м) серовато-голубого цвета с очковой (линзовидно-прожилковой) текстурой. Ядра линз сложены крупнокристаллическим ангидритом голубого цвета. Кристаллы ангидрита игольчатые, а вдоль трещин представлены сферически-лучистыми агрегатами. Межлинзовые зоны и края линз сложены мелкокристаллическим гипсом серого цвета. Гипс развивается по системе тонких трещин, по которым, вероятно, мигрируют растворы.

Гипсовая порода $(50,8-51,3$ м) серого цвета с сетчато-желваковой текстурой. Гипс мелкокристаллический слагает желваки линзовидно-овальной формы размером от 1 до 8 см. Межжелваковое пространство заполнено доломитом бежевого цвета. Доломит пелитоморфный, с цементирующими пойкилокристаллами гипса, выраженными только по спайности. Доломит разбит тонкими субпараллельными прожилками гипса толщиной до 0,5 мм.

Доломит (51,3-54,0 м) глинистый, органогенный, бежевого цвета. Структура органогенно-детритовая, местами пелитоморфная. Текстура породы неяснослоистая, волнистослоистая. Из органических остатков отмечены фузулиниды и еще что-то. Порода слабой и средней крепости, очень пористая, местами с крупными кавернами размером до $3 \mathrm{~cm}$.

Нижний слой неволинской пачки $(54,0-56,8$ м) сложен доломитом оолитовый бежевого цвета. Оойды размером от 0,5 до 1,5 мм, обычно округлой формы, редко встречаются овальные. Строение оойдов концентрически-зональное. Ядро оойдов либо пелитоморфоное, либо полое, либо замещено гипсом или кальцитом. Слойки вокруг ядра сложены пелитоморфным доломитом. Количество слойков колеблется от 1 до 6. Оойды цементируются пелитоморфным доломитом, местами пойкилитовым кальцитом или гипсом. В породе встречаются редкие раковины брахиопод, полностью замещенные кальцитом. На глубине 54,1 м прослеживается слоистая текстура породы. Слойки неритмичные толщиной от 1 до 5 см. На контактах некоторых прослоев отмечаются пологие стилолитовые швы амплитудой не более 5 мм.

Ледянопещерская пачка (56,8-81,0 м). В интервале 56,8-68,5 м сложена ангидритом серовато-голубого цвета. Структура крупнокристаллическая, агрегатного строения. 
Кристаллы ангидрита игольчатые, а вдоль трещин представлены сферическилучистыми агрегатами. Текстура породы однородная, осложненная тонкой сеткой взаимопересекающихся диагональных и субгоризонтальных прожилков глинистогипсового состава, толщиной от 0,5 до 5 мм.

Гипс-ангидритовая порода (68,5-72,5 м) от светло- до темно-серого цвета, с примазками и тонкими прослоями глины серовато-коричневого цвета. Доля гипса в породе больше, ангидрит встречается в виде сгустков, неравномерно распределенных по всей породе. Структура гипса мелко-, реже среднекристаллическая. Ангидрит мелкокристаллический. Текстура породы неяснослоистая, пятнистая. Порода крепкая, плотная, с редкими диагональными закрытыми трещинами.

Подошва пачки (подошва карстовой полости) 75,0 до 81,0 м представлена глиной от коричневого-черного до светло-кремового цвета, плотной. Иногда встречаются мелкие обломки гипса.

Филипповский горизонт (81,0-89,6 м) представлен доломитом глинистым от бежевого до светло-коричневого цвета, пелитоморфным, от тонкослоистого до среднеслоистого (слойки от 0,5 см до $10 \mathrm{~cm}$ ), с частыми вкраплениями кальцитовых псевдоморфоз двух типов. Первый тип - мелкие (до 4 мм в длину) веретенообразные агрегаты кальцита мелкокристаллического по кристаллам гипса синседиментационного генезиса. Второй - крупные псевдоморфозы кальцита (до 1 см) по звездчатым кристаллам гипса диагенетического генезиса. Кальцит заполняет пространство от периферии к центру. В некоторых местах гипс сохранился в центральной части пседвоморфоз. Порода в целом плотная, но отмечаются редкие каверны выщелачивания по гипсу. Трещиноватость субвертикальная и диагональная. По трещинам развиты налеты и дендриты гидроксидов железа и марганца.

Верхняя часть $(81,0-82,4$ м) сложена щебнем глинистого доломита в глинистой «рубашке».

\section{Выводы}

Скважина № 4444 подтвердила положение о том, что массив сложен переслаивающейся сульфатно-карбонатной толщей горных пород.

В обеих скважинах вскрыты отложения филипповского горизонта. В горизонте прослеживается падение слоев на С3, что согласуется с предыдущими данными (Перевозчиков, 1956; Дорофеев, 1974) Падение слоев иренского горизонта и вышележащих карстообвальных отложений N-Q не совпадает с падением филипповского горизонта и направлена на ЮЗ в сторону склона, что возможно, обусловлено гравитационными процессами.

В ходе дополнения литолого-стратиграфического разреза Ледяной горы были описаны породы демидковской и елкинской пачки, которые отсутствовали в разрезе скважины № 4443. Залегания елкинской пачки представлены в коренном залегании, что в пределах Ледяной горы встречается очень редко. Встреченные породы елкинской пачки позволили сделать выводы о том, что породы в склоновой части сохранились лучше, чем в центральной части. Мощность карсто-обвальных отложений в скважине № 4443 составляет 38 м, т.е. гораздо больше, чем в скважине № 4444 (7,3 м), что говорит нам о сильной деформируемости и выветрелости горных пород центральной части массива, нежели склоновой части. Предполагаемая зона деформации по разрезу находится в зоне развития поверхностных карстовых форм (карстовых воронок), расположенных в центральной части разреза (рис. 1). В обнажении этих воронок в интервале 192,5-195,6 встречен массивный серый гипс, предположительно являющийся ксенолитом демидковской пачки.

Исследование выполнено в рамках Программы ФНИ, проект № 0422-2019-0144-C-02 


\title{
БИБЛИОГРАФИЧЕСКИЙ СПИСОК
}

1. Герасимов Н.П., Тихвинская Е.И. Разрез классического кунгура // Зап. Всеросс. минерал, об-ва. 1934. - Т. 6, Вып. 2. - С.

2. Лукин В.С., Ежов Ю.А. Карст и строительство в районе г.Кунгура. Методика изысканий и опыт строительства в карстовых областях. - Пермь: Кн. изд-во, 1975. - 120 с.: ил.

3. Кадебская О.И., Калинина Т. А. Литологический разрез Ледяной горы // Комплексное использование и охрана подземных пространств: сб. докл. Междунар. науч.-практ. конф., посвящ. 100летнему юбилею науч. и туристско-экскурсионной деятельности в Кунгурской Ледяной пещере и 100-летию со дня рожд. В.С. Лукина / ГИ УрО РАН; под общ. ред. О. Кадебской, В. Андрейчука. Пермь, 2014. - С. 42-49.

4. Катаев В.Н., Кадебская О.И. Геология и карст / ПГУ, ГИ УрО РАН. - Пермь, 2010. - 249 с.: ил.

5. Кунгурская ледяная пещера: опыт режимных наблюдений / ГИ УрО РАН; под ред. В.Н. Дублянского; [отв. ред. А.И. Кудряшов]. - Екатеринбург, 2005. - 376 с.: ил.

6. Ожгибесов В.П. Геология «Предуралья» // Вестн. Перм. ун-та. Сер. Геология. - 2000. - № 3. C. $70-112$.

DOI:10.7242/echo.2020.4.6

\section{ЭКОГЕОХИМИЧЕСКАЯ ОЦЕНКА ТВЕРДЫХ КАЛИЙНЫХ ОТХОДОВ НА ОСНОВЕ СОДЕРЖАНИЯ МИКРОЭЛЕМЕНТОВ}

\author{
Е.С. Хохрякова \\ Горный институт УрО РАН, г. Пермь
}

\begin{abstract}
Аннотация: Проведена оценка токсичности твердых отходов калийного производства Верхнекамского месторождения на основе анализа содержания в них микроэлементов. Сопоставление с фоновыми концентрациями микроэлементов в почвах Березниковско-Соликамского промрайона показало повышенное содержание в отходах $\mathrm{V}, \mathrm{Ni}, \mathrm{Cr}, \mathrm{Zn}, \mathrm{Co}, \mathrm{Pb}, \mathrm{Cd}$. Установлено, что максимальные их концентрации связаны с нерастворимым остатком глинисто-солевых шламов.
\end{abstract}

Ключевые слова: Верхнекамское месторождение солей, галитовые отходы, глинисто-солевые шламы, содержание микроэлементов, токсичность горных отходов.

\section{Введение}

Основное негативное воздействие калийных предприятий Верхнекамского месторождения (ВКМС) на окружающую среду связано с накоплением на поверхности твердых отходов (галитовые породы, глинисто-солевые шламы). К числу основных макроэлементов данных отходов относятся хлориды кальция и натрия, к микроэлементам - щелочные и щелочноземельные металлы (стронций, барий, литий, рубидий), полуметаллы (бор, мышьяк, селен, германий), тяжелые металлы, бромиды, аммонийный азот.

Различными исследователями в рудах и отходах ВКМКС обнаружено около 30 микроэлементов [2], среди которых с экологической точки зрения обращает на себя внимание группа тяжелых металлов (ТМ). Сравнение результатов исследований содержания ТМ обнаруживает некоторые расхождения, хотя общий уровень практически одинаков. Расхождения связаны прежде всего с латеральной изменчивостью концентраций ТМ как по отдельным шахтным полям, так и по месторождению в целом. Кроме того, определенные различия связаны и с погрешностями применяемых аналитических методов при исследовании высокохлоридной матрицы.

Задачей настоящего исследования являлось сопоставление уровня накопления микроэлементов в отходах, складируемых в отвально-шламовом хозяйстве, с принятыми экологическими нормативами для окружающей среды, в первую очередь, для почв. В 